\title{
Corporate Social Responsibility: A Study Of Progression To The Next Level
}

Sam Cooper, Texas A\&M University - Kingsville, USA

George Wagman, Ph.D., Texas A\&M University - Kingsville, USA

\begin{abstract}
Corporate Social Responsibility was an initiative constructed many years before its popularity or implementation. The 2001 economic state, local, and world affairs brought this inspiration to the front of actionable items. The terrorist attacks of September 11, the collapse and scandals of Enron, WorldCom, and Tyco left thousands without their retirement. The bankruptcy of many ancillary businesses and similar corporations are excellent examples of imbalanced management. Other examples of poor silo-style management have proliferated through many organizations serving as the root cause for the adoption of socially responsible initiatives. Corporations over the past fifty years have made attempts at serving greater causes. However, these initiatives were simply a random string of projects, which were short in duration. Further they were sporadic in nature, small, and did not compliment other projects benefiting the community. Projects were based on volunteerism and little else. Some influence by a peer might inspire a reluctant person to participate once but rarely a second time. Albeit, corporations encouraged their employees to be active with these projects; corporate money was seldom used as it would inspire these causes to request additional funds. At that time, corporate sponsored social responsibility within society was the exception and not the rule. Today's companies are measured by their initiatives of corporate social responsibility. Public companies are including environmental and social accountability in their Securities and Exchange Commission documents. Massive air time is being devoted to market social responsibility and a company's compliance with a demanding public. Corporate social responsibility can now be measured as the extra mile.
\end{abstract}

Keywords: social responsibility, accountability, ethical leadership.

\section{SUMMARY OF LITERATURE REVIEW}

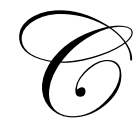

orporateSocial Responsibility has been present, in one form or another, for the past fifty years. Volunteerism began out of social need which several or many individual participants could address. This type of program served a sustainable purpose with a positive outcome. However, volunteerism benefited few and did not connect with higher endeavors. The corporate position was to support the spirit of volunteering but did not financially endorse the effort, at least substantially.

Today social responsibility is a conscience effort driven by the highest levels of management. Organizations are training their people to present a congruent message to customers, stakeholders, and the general public. The Human Resources function has been identified as the pivotal organization to make this initiative possible. Corporations, with the help of Human Resources, are developing new mission statements and philosophies that will support the social aspect of the business. New marketing plans along with a code of ethics for all employees are being constructed. These plans will serve as rules of interaction for organizations such as the National Association of Insurance and Finance Association (NAIFA) (Taggart, 2008).

Corporations, government entities, and universities are training and managing efforts of all sizes. The International Standards Organization is actively creating the ISO26000 set of standards for social responsibility. Trade schools and universities have been teaching business ethics for the past several years. Even though business ethics classes are dwindling within universities, the real education begins in the corporate setting (Stoll, 2008). 
Some companies are struggling to delineate between social accountability and directing a for-profit business. The fiduciary duty to operate an organization and maintain corporate readiness seems to collide with the suggestion of a corporation's role with social responsibility (Stoll, 2008). The company will always be a profit generating entity. Blending social responsible initiatives will further force the organization to grow in a more utilitarian approach. However, all the involved parties will have the knowledge that in the course of business, someone or some cause will benefit from their social efforts (Wettstein, 2008).

Power struggles are now being defined around socially accountable projects. Private agendas and personal wealth are becoming entangled. It is very possible to have a successful business and social reforms while massing personal wealth. The idea of relationship building is to project resources from the corporation into the local community (Kleinrichert, 2008).

The organization of the future will be a correlation of large and small companies, with large numbers of individual contributors. With the training in corporations and universities, the individual will begin to sponsor projects and corporations that exhibit moral and social standing. Individuals will begin to invest their time, including their families and friends, as well as their money into environmentally or socially acute companies. One of the investment questions today is; do I invest in a company that has direct influence in a social program or donate invested funds into social causes (Statman, 2008)?

Small companies are beginning to combine their resources to gain visibility and clarity. With efforts in creating guidelines from organizations such as the International Standards Organization, the smaller entity will gain access to a level of knowledge that was not possible before.

Small companies are now lobbying the individual contributor for assistance; and it is working. The inclusion of the public at large will give a new sense of ownership to causes and projects that need an infusion of dedication and muscle. Companies are requesting the public to recycle magazines. Recycling has been met with mediocre results and in some communities has all but failed. However, when a small business owner from the New York area and the Governor come together to sponsor a recycling program and demonstrate its benefits; this seems to solidify the effort and is an example of 360 degree activism. (NYC Mayor Bloomberg Praises Pratt, 2008).

\section{CONTROLS}

With new processes and technology, controls will be defined. Several organizations have made efforts to define sections or the entire sphere of corporate social responsibility. Functional guidelines have been crafted proposing the structure necessary to carry out managerial, accounting and audit functions (Reynolds, Yuthas, 2008).These organizational efforts add a tremendous amount of confusion when making decisions on reporting as they are all vying to be the defacto standard. The following is a list of leading control companies:

1. $\quad$ EMAS (European, particularly German environmental management and audit)

2. ISO 14001 (Internationally recognized environmental management certification)

3. SA 8000 (Social Accountability International labor standard).

4. AA1000 (International accountability assurance reporting standard).

5. Copenhagen Charter (International standard involving stakeholder communications).

6. GRI (Global Reporting Initiative) 2000 (International sustainability report).

(Reynolds, et al, 2008)

For the purposes of this document, the standards of reporting for stakeholders as defined by the Copenhagen Charter will be used. The Copenhagen Charter serves as a framework to create and maintain dialogue and accountability between a company and its stakeholders. The framework requires emersion with corporate strategies, business plans, code of ethics, standard operating procedures, and core values. The process is built on a three tier model, which includes the foundation, adapting the process, and disseminating outcomes (The Copenhagen Charter, 1999). 
The model is driven by communication standards. Stakeholders are involved early in the process and become active participants. Executives and stakeholders define key performance indicators and these are used as determinants of success. Progress is monitored and course adjustments are made accordingly. Budget and actionable plans are developed, as well as, process improvement, which will serve as projects plans. Reports are prepared and disseminated to the executives and stakeholders for review or course corrections. During these steps, the process requires a vigorous dialogue between all parties to establish trust and improve value.

The following is a diagram, according to the Copenhagen Charter (1999), of the reporting process:

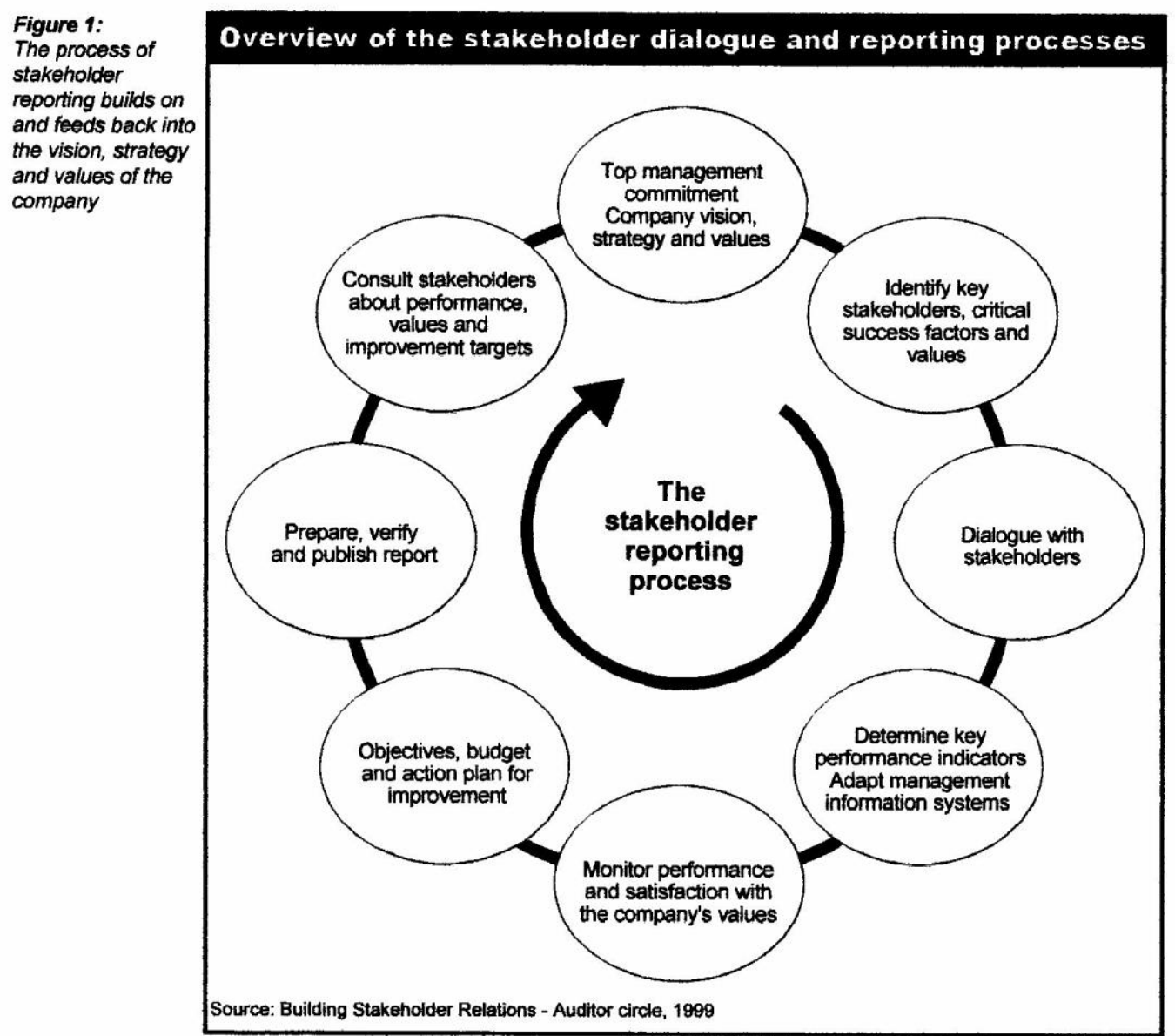

\section{STAKEHOLDER APPROACH}

A stakeholder, as defined by Daft (2008), "is any group within or outside the organization that has a stake in the organizations performance". Stakeholders are key participants in corporate social responsibility and play pivotal roles as they economically and politically encapsulate the organization.

Sirgy and Lee (2008) delineate shareholders into three distinct groups. The 1) internal stakeholder operates within a business unit or functional department. 2) External stakeholders operate outside the company and have a stake in the company's performance. 3) Distal stakeholders are adjacent to the external stakeholders and exhibit control over the company through external shareholders, such as the government or environmental groups.

We have accounted for the requirement of a communication framework to bolster stakeholder interaction and establish a foundation of mutual trust. Stakeholder marketing and investment are a natural extension of the 
framework started by the Copenhagen Charter. The traditional marketing model is transactional in nature. Transactional marketing is tightly based on economics and is used specifically to generate the highest profit margin. This model serves its purpose of revenue generation well and has its place within marketing as maximizing profit is part of social responsibility. However, the relational model is better suited to marketing to stakeholder (Sirgy, et al, 2008).

Relationship based marketing has surfaced as a technique which markets to a person based on principles and ethical behavior. This establishes long-term continuity and invokes the desire of all parties to participant to the fullest extent. According to Morgan and Hunt (1994), relationships built on this type of marketing further encourage the creation, development, and preservation of future partnerships between executive and stakeholder. This type of transaction further improves business interactions from the individual contributor to the executive.

Reynolds, et al (2008) expressed that corporate social responsibility framework exceeds the requirement for strategy management or consultation and creates a stakeholder commitment. The operation is now susceptible to more meaningful dialogue, execution, and confident investment by those who rely on the business function.

\section{EXECUTIVE LEADERSHIP}

Sound ethical leadership is comprised of loyalty, empathy, honesty, and integrity which are part of every decision and behavior. It is important the management, from lower tier to executive, must reinforce ethical behavior to the company base. Reviews, compensation agreements, and objectives should be used as tools to guide the individual into the ethical sphere of influence (Daft, 2008). The goal is to have the entire enterprise project sound ethical behavior to stakeholders and the community.

Individuals are at times called to serve at the helm of the organization. Job specific training is of great use, however, training and execution in the social realm is critical; internally and externally. This individual will experience a wide breadth of challenges that will require leadership skills.

Transactional leadership gives way to monetary and objective offerings. Further, this management style intervenes only when performance goals are not met and attention weighs towards the bottom line (Den Hartog et al., 1997; Gini, 1998; Odom and Green, 2003; Wren, 1998). Organizations which do not exhibit change or growing pains typically fall into the transactional category. These organizations are at the effect and often stymied. Absent of ethical leadership, this organization will invite outside scrutiny, usually from stakeholders, to correct the self-serving and standalone tendencies.

Transformational leadership is comprised of teamwork, continuous improvement, strategic vision, values, sustainability, and executes relational transactions (Sama, Shoaf, 2008). Sound ethical leadership is about a utilitarian mind set and inspiring contributors to extend their reach. It meets the goals of the majority and exercises good judgment based on morality and truthfulness. Ethical leaders find ways to persuade others to carry their message and curb undesirable behavior. The development of this type of character never stops; learning and assimilation are constant.

Reaching professional status is an earned benefit and must be treated as such. The respect given to the profession, by society, must be achieved consistently. Ethical business relationships must produce shared benefits for all involved. Sama et al (2008) state these shared duties consist of honest information and shun deceit or deceptive practices. Further, ethical leaders adhere to privacy and confidentiality while intending harm to no one.

\section{RETENTION OF EMPLOYEES}

The retention of employees is typically based on company performance and how the company compares to others in a similar size and market. Corporate social performance is a new measurement of how effective the company is with its social responsibility efforts and the company's retention. According to (Coldwell, Billsberry, Meurs, Marsh, 2008) the individuals perception to the person-organization fit is based on 1) magnetism of the company to prospective employees and 2) the characteristics of the employee's actions. 
Prospective employees want many things. This includes excellent pay, matching $401 \mathrm{~K}$, health insurance, life insurance, and vacation among others. However, these items are a baseline and offered at the majority of hiring employers. So what is the differentiator? According to Coldwell et al (2008) people what to feel good about where they work. Cash is no longer king. Values are now highly sought after and they create motivation within the company. Executives are spinning out value programs to the employee base and allowing them to decide what form the programs will take. However, these programs are given a business objective to solve and they have shown positive measurable results in turnover have occurred in several companies.

Cable and Judge (1996) illustrated that the corresponding values of employer and employee is gauged to job satisfaction, organizational obligation, willingness to remain, and real retention. Further, people are not drawn to organization where they believe they will fit; rather the act of joining and integrating to the organization's values is the natural characteristic. The real issue is older than social responsibility itself; the organization and the individual share in mutuality and one enables the other.

\section{CONCLUSION}

Corporate social responsibility has matured from a small volunteer sample to corporate directed initiatives with officer level support. This effort now addresses opportunities in many areas, which include employees, stakeholders, economic well-being, sustainability, environmental growth, legal morality, community support, and discretionary support.

The executive, with proper education and professional tenure, must now cultivate a new set of skills. Leadership now includes motivation, empathy, trust, vision, values, and continuous improvement. These skills are prerequisite to the role of ethical professional. There remainder of the employee base has the opportunity to absorb and integrate these skill into their own persona. This will encourage a congruent behavior, within the organization, which is desirable and marketable.

Companies must transact business on a higher plane. For some time now, relationship based interaction has been suggested as a target objective. Relational base motives and transformational mind set inspires the relationship experience to move to the next level. This interaction promotes forward thinking and problem solving on a peer level. Further, it inoculates the employee base from transactional base selling, managing, and thinking.

Employees have more requirements for an employer than the standard set of benefits. Employees are looking to be inspired and lead. The individual wants to feel good about their employment choice. Given all things are equal; the individual contributor will join the organization that is culturally and personally congruent with their values.

\section{RECOMMENDATIONS}

Corporate social responsibility has made significant growth over the last ten years. Policy creation, organizational guidelines, management guidelines, key performance indicators, best practices, and core values have been created or improved upon.

This philosophy can be easily transitioned into a service offering that can be marketed by consulting and management firms. Establishing a practice for this initiative and creating grades for potential candidates will serve to create an industry wide service offering. The control organizations must be fused into one core practice and set as the defacto standard. Guidelines must be established for grades and levels of certification. These steps will create a resource pool of professionals, which will proliferate measurable corporate social responsibility efforts to society.

\section{AUTHOR INFORMATION}

Sam Cooper is a Masters of Business Administration candidate at Texas A\&M University - Kingsville. He possesses eighteen years experience in management, business development, and information technology in the 
consultancy field. Mr. Cooper has executed these duties for PricewaterhouseCoopers, Cap Gemini Ernst \& Young, and Digital Equipment Corporation.

George R. Wagman, Professor of Management at Texas A\&M, University Kingsville, Texas.

\section{REFERENCES}

1. Cable, D. M., Judge, T.A. (1996) Person-Organization Fit, Job Choice Decisions, and Organizational Entry; Organizational Behavior and Human Decision Processes, Issue 67, 294-311.

2. Carroll, A. B., Buchholtz A. K. (2000) Business and Society, 5th edition; South-Western, Ohio.

3. Coldwell, D., Billsberry, J., Meurs, N., Marsh, P. (2008) The Effects of Person-Organization Ethical Fit on Employee Attraction and Retention: Towards a Testable Explanatory Model. Journal of Business Ethics; Vol. 78 Issue 4, 611-622.

4. $\quad$ Daft, R. L., Lane, P.G. (2008) Management $8^{\text {th }}$ ed.: New York: Thompson South-Western.

5. Den Hartog, D. N., van Muijen, J.J. and Koopman, P.L. (1997) Transactional versus Transformational Leadership: An Analysis of the MLQ. Journal of Occupational and Organizational Psychology; Vol. 70 Issue 1,19-29.

6. Ernst \& Young, KPMG, PricewaterhouseCoopers, House of Mandag Morgen (1999) The Copenhagen Charter: a management guide to stakeholder reporting: House of Mantag Morgen.

7. Gini, A. (1998) Work, Identity and Self: How We Are Formed by the Work We Do. Journal of Business Ethics;_Vol. 17 Issue 4, 707-714.

8. Kleinrichert, D. (2008) Ethics, Power and Communities: Corporate Social Responsibility Revisited. Journal of Business Ethics; Vol. 78 Issue 3, 475-485.

9. Morgan, R. M., Hunt, S.D. (1994). The Commitment-Trust Theory of Relationship Marketing, Journal of Marketing Vol. 58, 20-38.

10. NYC Mayor Bloomberg Praises Pratt. (2008) Official Board Markets; Vol. 84 Issue 5, 13.

11. Odom, L. and Green, M.T. (2003) Law and the Ethics of Transformational Leadership. Leadership \& Organization Development Journal; Vol. 24 Issue 1/2, 62-69.

12. Reynolds, M., Yuthas, K. (2008) Moral Discourse and Corporate Social Responsibility Reporting. Journal of Business Ethics; Vol. 78 Issue 1/2, 47-64.

13. Sama, L., Shoaf, V. (2008) Ethical Leadership for the Professions: Fostering a Moral Community. Journal of Business Ethics; Vol. 78 Issue 1/2, 39-46.

14. Sirgy, J.M., Lee, D.J. (2008) Well-being Marketing: An Ethical Business Philosophy for Consumer Goods Firms. Journal of Business Ethics; Vol. 77 Issue 4, 377-403.

15. Statman, M. (2008) Quiet Conversations: The Expressive Nature of Socially Responsible Investors. Journal of Financial Planning; Vol. 21, Issue 2, 40-46.

16. Stoll, M. (2008) Backlash Hits Business Ethics: Finding Effective Strategies for Communicating the Importance of Corporate Social Responsibility. Journal of Business Ethics; Vol. 78 Issue 1/2, 17-24.

17. Taggart, J.J. (2008) Living by the Code. Advisor Today; Vol. 103 Issue 2, 10.

18. Wettstein, F. (2008) Let's Talk Rights: Messages for the Just Corporation-Transforming the Economy Through the Language of Rights. Journal of Business Ethics; Vol. 78 Issue 1/2, 247-263.

19. Wren, T. (1998) James Madison and the Ethics of Transformational Leadership in J. Ciulla (ed.) Ethics: The Heart of Leadership (Praeger, Westport CT). 